\title{
"Nem toda AlelUia É UMA ALELUiA": ACERCA DA CATEGORIZAÇÃO METAFÓRICA NA NARRATIVA FICCIONAL
}

\section{"Not every hallelujah is a hallelujah": on metaphoric re-categorization in fictional narrative}

\author{
Diogo de França Gurgel*
}

\begin{abstract}
RESUMO
Neste trabalho, faço uma introdução à abordagem da metáfora feita pelo Modelo da Inclusão em Classe, o qual vem sendo elaborado por Sam Glucksberg e Boas Keysar desde a década de 1990. Procuro mostrar sua superioridade com relação à visão comparacionista e proponho também alguns complementos ao modelo com vistas a torná-lo mais compatível com certos tipos de metáfora com os quais nos deparamos em narrativas ficcionais.
\end{abstract}

Palavras-chave: metáfora; símile; categoria.

\begin{abstract}
In this paper, I introduce the approach to metaphor taken by the Class-Inclusion Model, which has been developed by Sam Glucksberg and Boas Keysar since the 1990s. I look forward to showing their superiority with respect to the comparison view, and I also propose some additions to the model in order to make it more suitable to certain types of metaphor with which we are faced in fictional narratives.
\end{abstract}

Keywords: metaphor; simile; category.

* Universidade Federal Fluminense. 


\section{INTRODUÇÃo}

Todas as categorias funcionais em nossa linguagem possuem um nome que lhes é próprio - eis uma postulação temerária. Nossas atividades cotidianas são repletas de exemplos em contrário: a classe dos objetos que não devem ficar à vista das visitas que nome leva? Que nome leva o conjunto dos termos que não se pode usar em uma entrevista de emprego? Em detrimento da ausência de nomes para tais categorias, podemos considerá-las funcionais na medida em que somos capazes de determinar seus membros de modo satisfatório e de agir de acordo com essa determinação (i.e., na medida em que somos capazes de ocultar roupas íntimas, joias, evidências de um crime - como no Festim Diabólico de Hitchcock - ao recebermos visitas em casa, e de evitar termos chulos, termos excessivamente cômicos, e certas confissões no contexto de uma entrevista de emprego.

Mas, se em nossa linguagem ordinária temos o nascedouro dessas categorias funcionais, porém, anônimas, no texto literário encontramos sua pia batismal. Apresentarei, no que se segue, as razões que me levam a afirmar que, ao lermos o Doutor Fausto, de Thomas Mann, colaboramos com a captura, mediante o emprego do nome "refúgio", da categoria das coisas que permitem a um artista apartar-se das convenções sociais em busca de seu grande estilo e que, ao lermos Água Viva, de Clarice Lispector, colaboramos com a captura, mediante o emprego do nome "aleluia", da categoria das manifestações exclamativas de um tipo de felicidade diabólica. É sabido que encontrar modos satisfatórios de caracterização de categorias anônimas está entre os maiores desafios do literato, mas, nessa esteira, pergunto: não seria a nomeação dessas categorias um esforço de síntese que frequentemente requer o estabelecimento de uma metáfora?

O Modelo da Inclusão em Classe, proposto por Sam Glucksberg e Boas Keysar na década de 1990, com sua tese central de que metáforas nominais são recursos de nomeação de categorias ad hoc (de ocasião) mediante a alteração da extensão do conceito articulado em seu veículo (designado pelo termo do predicado), é promissor para o trabalho com metáforas literárias. As transgressões normativas e inovações semânticas de autores como Mann e Lispector exigem uma concepção que não sucumba ao reducionismo da teoria da metáfora mais disseminada da história do Ocidente, o Comparacionismo - refiro-me àquela concepção de metáfora condensada por Quintiliano na fórmula "metáfora é símile abreviado" (QUINTILIANO, 1953, VIII, vi, 8-9) e ainda defendida em nossos dias por autores como George Miller e Andrew Ortony.

Procurarei mostrar que o modelo de Glucksberg e Keysar supera

o Comparacionismo ao permitir uma abordagem mais satisfatória daquela 
veemência ontológica presente em certas metáforas, as quais não se deixam exprimir na forma de símile. Contudo, ainda que tal modelo seja consideravelmente flexível, a ponto de comportar composições de engenho, erigidas nas bordas da comunicabilidade, ele peca justamente por sua pretensão de oferecer uma fórmula única para o que suspeito não ser uma operação única e sim uma família de operações. Dada essa minha suspeita, vejo-me impelido a fazer mais do que uma simples exposição do modelo. Naqueles momentos em que os exemplos exigirem, apresentarei algumas propostas de complementação do mesmo. Tais propostas girarão em torno das seguintes evidências: a) ocorrem, em textos literários, casos de metáforas cujos protótipos são construídos ao longo da narrativa; b) ocorrem, em textos literários, casos de negações metafóricas (proposições em que ocorre uma negação); c) ocorrem, em textos literários, casos de metáforas que nomeiam categorias muito exclusivas, i.e., que só abarcam em sua extensão um rol muito seleto de membros.

\section{Protótipos E CATEgorias ANÔNIMAS}

O Modelo da Inclusão em Classe, apresentado por Sam Glucksberg e Boaz Keysar em artigo de 1990, denominado "Understanding Metaphorical Comparisons: Beyond Similarity", é fruto de um estudo sobre o modo como metáforas podem nos servir para descrever, definir, classificar,... em suma, para a sistematização dos estados de coisas em geral. Seus autores defendem - tendo por base um grande número de experimentos - que as metáforas possuem modos de promover categorizações que lhes são próprios, ou seja, que certas categorias - compreensíveis e aptas nos contextos em que lhes competem - somente poderiam ser engendradas e nomeadas via metáfora. E nisso eles se opõem diretamente a toda uma tradição milenar - mas ainda viva - que vê na metáfora uma função fundamentalmente ornamental.

Para uma compreensão mais apropriada da proposta de Glucksberg e Keysar, faz-se imprescindível um exame de seus dois alicerces fundamentais, a saber, a Teoria do Protótipo, desenvolvida por Eleanor Rosch e colaboradores, e a tese desenvolvida por Lawrence Barsalou de que frequentemente formamos categorias funcionais de ocasião ( $a$ d hoc) para orientar nossas ações. Nesta seção, farei uma breve exposição dessas duas teses.

Wittgenstein, antes do meio do século XX, já nos advertia quanto ao fato de que, na linguagem ordinária, raras são as ocasiões em que usamos conceitos nos moldes fregeanos, i.e., conceitos com limites extensionais rigidamente estabelecidos (WITTGENSTEIN, 2006, §71). Em suas Investigações Filosóficas, ele sublinha, reiteradamente, o fato de que as fronteiras dos conceitos da linguagem ordinária são geralmente difusas (fuzzy). Convida-nos a 
questionamentos como: quando ocorre exatamente a passagem do fenômeno que classificamos como chuva àquele que classificamos como tempestade? 0 conceito, na linguagem ordinária, tem a vagueza como elemento endógeno. o que é o comum e natural, pensa Wittgenstein, é o aprendizado dos usos dos signos e não de sua definição. Provocações como essas exerceram sua influência sobre a psicóloga cognitiva Eleanor Rosch no momento em que desenvolvia seu trabalho de maior expressão. Ao longo da década de 1970, Rosch explora - tendo por base os trabalhos de psicolinguistas como Labov, Berlin e Kay - os modos pelos quais um certo exemplar típico de uma categoria opera como ponto de referência cognitivo para a estruturação dessa categoria. Esse exemplar típico passa a ser denominado "protótipo".

A partir de experimentos feitos com indivíduos da tribo Dani, de Nova Guiné, e com estudantes universitários estadunidenses, Rosch conclui que costumamos considerar membro de uma categoria aquele objeto que compartilha, de modo suficiente, das propriedades salientes (relevantes) do protótipo. Quanto menos propriedades salientes são compartilhadas entre o protótipo e o objeto avaliado nas bases do mesmo, menos segurança temos na categorização (aumenta, por exemplo, o tempo de resposta ${ }^{1}$ ). Assim, o conceito prototipicamente formado apresenta uma estrutura graduada (escala de tipicalidade). A descoberta da estrutura graduada tem grande impacto sobre as teorias da categorização. Ela apresenta três aspectos: a) certas instâncias são melhores exemplos da categoria do que outras (a bola de futebol americano é menos tipicamente bola do que uma bola de tênis). Experimentos de verificação dão conta de que os membros prototípicos são categorizados mais rapidamente que os não-prototípicos, e que são os mais facilmente aprendidos; b) ocorrência de casos de borda, envolvendo dúvida acerca da pertinência de seu pertencimento à categoria (uma criança joga a bola na parede e pega de volta - temos aí um jogo²?); c) não-membros da categoria também variam no que diz respeito ao quão similares eles são ao conceito da categoria (demora-se mais para rejeitar um morcego como membro da categoria dos pássaros do que para rejeitar uma cadeira) (BARSALOU, 1983, p. 211).

Os trabalhos de Rosch sobre o tema do estatuto cognitivo das categorizações não se limitam, contudo, às relações internas (ou horizontais) entre os membros de uma categoria. Explorando as relações de subordinação entre categorias, a psicóloga e seus colaboradores delineiam uma estrutura

1 Vale notar que, tal demora no tempo de resposta nem sempre é tomada pelos pesquisadores da área da psicologia cognitiva como indício de dificuldade cognitiva. Em diversos contextos, essa demora sinaliza também dificuldade de aceitação e/ou dúvida.

2 Exemplo extraído de Wittgenstein $(2006, \S 66)$. 
intercategorial hierárquica (vertical) dividida em três níveis: supraordenado, base e subordinado (ROSCH, 1978; ROCSH et al., 1976). No nível básico, os conceitos apresentam equilíbrio entre informatividade (medida por quantidade de propriedades) e economia (medida pela facilidade com que se determina suas propriedades distintivas). O conceito que cai no nível supraordenado carece de informatividade e o conceito que cai no nível subordinado carece de economia. Um exemplo: experimentos feitos com alunos universitários estadunidenses revelou que, naquela comunidade, o termo "cadeira" é situado ao nível básico de uma estrutura intercategorial que tem "móvel" como nível supraordenado e "poltrona" como nível subordinado (ROSCH, 1978, p. 33). De acordo com Rosch, categorias de nível básico sempre são nomeadas nas culturas em que constam como tal: são as primeiras que as crianças aprendem, as de mais fácil identificação e as mais comumente empregadas.

A Teoria dos Protótipos integral, que inclui a classificação desses três níveis da estrutura intercategorial estabelecida por Rosch e seus colaboradores, encontrou grande número de entusiastas e teve importantes desdobramentos. Dentre estes, destaca-se o trabalho de Lawrence Barsalou acerca de categorias funcionais de ocasião (ad hoc). Categorias ad hoc seriam aquelas que as pessoas construiriam para certos objetivos específicos-como, por exemplo, "itens que devem ser levados para uma viagem de acampamento" e "lugares para procurar por escrivaninhas antigas" (BARSALOU, 1983, p. 211) - e se distinguiriam de categorias comuns, ou canônicas ${ }^{3}$, na medida em que violam as estruturas correlacionais do ambiente e não são facilmente memorizáveis. Por outro lado, têm em comum o fato de que os graus de tipicalidade de seus membros obedece a estrutura graduada de um protótipo (conceito da categoria).

No que diz respeito a categorias comuns (canônicas), Barsalou assume, seguindo trabalhos tardios de Rosch, os quais promovem uma revisão do conceito de protótipo, "que o conceito de uma categoria é a média de todas as instâncias da categoria e que a tipicalidade de uma instância cresce conforme ela se mostra mais similar ao conceito da categoria". No caso de categorias ad hoc, o conceito da categoria não seria uma média, mas só conteria "as propriedades das instâncias que são relevantes para o objetivo a que serve essa categoria" (BARSALOU, 1983, p. 225).

Glucksberg e Keysar bebem na fonte de Barsalou na medida em que compreendem que as metáforas são recursos de nomeação ou mesmo de

3 Optarei, neste trabalho, por caracterizar tais categorias como "canônicas" e não como "comuns" para não incorrer no que me parece ser uma homogeneização ingênua das práticas sociais tão diversas que encontramos em linguagens correntes. $O$ uso de um signo em um contexto altamente técnico pode ser "canônico" naquele contexto, ainda que não seja "comum". 
estabelecimento de categorias ad hoc. Vejamos a seguir como eles compõem seu Modelo de Inclusão em Classe.

\section{O Modelo de Inclusão em Classe (MIC)}

Glucksberg e Keysar, em trabalhos publicados desde a década de 1990, vêm defendendo a tese de que a compreensão de uma metáfora nominal como "A raiva é um vulcão" não envolve uma correspondência de características (feature matching) entre o referente do tópico "raiva" e o referente do veículo "vulcão" - como concebe o modelo Comparacionista. Afirmam os autores que a compreensão de uma sentença como essa se dá da maneira mais evidente e imediata, ou seja, respeitando-se a forma assertiva (" $a$ é $b$ ") que é a sua.

Metáforas não são compreendidas com base em sua transformação em símiles. Ao invés disso, elas são concebidas como declarações de inclusão em classe e são compreendidas como tal. Quando metáforas são expressas como comparações (i.e., como símiles), então elas são interpretadas como declarações de categorização implícita, ao invés do inverso. (GLUCKSBERG; KEYSAR, 1990, p. 16)

Como se vê, os autores se empenham em desafiar o tradicional modelo Comparacionista, que tem sua sedimentação entre os retores latinos - sobretudo na obra de Quintiliano, para quem a metáfora seria símile abreviado-, defendendo "que metáforas são exatamente o que elas parecem ser: asserções de inclusão em classe" (GLUCKSBERG; KEYSAR, 1990, p. 3). $\mathrm{Ou}$ seja, eles assumem que a sentença metafórica tem natureza proposicional, de modo que, "quando as pessoas usam metáforas, elas estão dizendo [saying] exatamente o que querem dizer [mean]" (GLUCKSBERG; KEYSAR, 1993, p. 401). Decerto, ao nos depararmos com tal assunção, uma pergunta se impõe de imediato: como, então, poderia ser feita a distinção entre o sentido metafórico e o sentido literal de uma sentença?

De acordo com Glucksberg e Keysar, a metáfora promoveria categorizações por vias distintas daquelas que chamamos de literais: o veículo (conceito expresso no predicado da metáfora) tipificaria não uma categoria canonicamente estabelecida (taxionômica) e sim uma categoria de ocasião ou ad hoc (no caso, vulcão tipificaria a "categoria de coisas que se insurge inesperadamente e pode causar estragos") e a raiva constaria entre os membros dessa categoria ad hoc (KEYSAR et al., 2001, p. 435), a qual incluiria "uma variedade de membros tais como epidemias, revoluções, raiva, e assim por diante" (KEYSAR et al., 2001, p. 435). Assim, "Poás é um vulcão" e "A raiva é 
um vulcão" seriam ambas sentenças assertivas, contudo, somente no segundo caso a palavra "vulcão" designaria uma categoria ad hoc e supraordenada (superordinate) ${ }^{4}$. Chamemos essa concepção de metáfora desenvolvida por Glucksberg e Keysar de Modelo de Inclusão em Classe (doravante, MIC).

O MIC assume não apenas que o veículo da metáfora tipifica a categoria ad hoc criada, mas também que o mesmo empresta seu nome para essa categoria (KEYSAR et al., 2001, p. 435). Essa posibilidade já havia sido aventada por Roger Brown em artigo de $1958^{5}$. Os autores adotam o insight de Brown de que a metáfora produz uma alteração na extensão de um conceito demarcada pela transferência de um nome. De acordo com essa tese, o termo que nomeia o veículo passa a designar mais indivíduos, o que lhe permite nomear uma categoria ainda anônima. A operação metafórica se constituiria, portanto, como uma operação de alteração da extensão de um conceito (o veículo da metáfora), de modo que ele possa abarcar o referente do termo que ocupa a posição de sujeito (o tópico da metáfora). Nessa operação, certas propriedades do protótipo da categoria canônica que tomamos como propriedades típicas devem ser postas de lado. Mas aquelas que se mantêm em relevo ainda são algumas daquelas que canonicamente são tomadas como típicas. Ou seja, os membros prototípicos da antiga categoria continuam sendo membros prototípicos da nova categoria.

Para deixar mais claro esse ponto, consideremos um outro exemplo fornecido por Glucksberg e Keysar: no caso da metáfora "Meu trabalho é uma prisão", certas propriedades prototípicas de prisão, tais como "reter contra a vontade" e "ser desconfortável", são mantidas e outras, tais como "ter barras de ferro", "ter a porta trancada", as quais servem para a organização do conceito canônico de prisão, são ocultadas. Mediante esse jogo de destaque e supressão de proprieades, formar-se-ia a categoria funcional ad hoc nomeada "prisão".

Chamo a atenção para o fato de que afirmar, como o fazem Glucksberg e Keysar, que categorias engendradas e nomeadas por metáforas são ad hoc significa dizer que as mesmas são formadas com base em um objetivo muito peculiar ao contexto (que são "funcionais", na terminologia de Barsalou). O que significa dizer, também, que categorias metafóricas são um caso especial de categorias funcionais recém-criadas e que, como tais, devem ter estrutura graduada (GLUCKSBERG; KEYSAR, 1993, p.419).

4 Adotando a terminologia de Rosch, podemos dizer que, na concepção da metáfora como inclusão em classe, o nome de uma categoria de nível básico (basic-level) passaria a designar uma categoria de nível superior (superordinate).

5 "Metaphor differs from other superordinate-subordinate relations in that the superordinate is not given a name of its own. Instead, the name of one subordinate (i.e., the vehicle) is extended to the other." (BROWN, R., apud GLUCKSBERG; KEYSAR, 1993, p. 411). 


\section{Categorias supraordenadas ad hoc estabelecidas por metáfora}

Devidamente expostas as linhas mestras do MIC, vejamos agora como ele nos serve no exame de certas inovações semânticas ocorrentes em narrativas ficcionais. Forneço abaixo o que me parece ser um belo exemplo da maneira como uma metáfora pode preencher certas lacunas de nossa linguagem, nomeando uma categoria anônima de ordem superior. Trata-se de uma passagem do Doutor Fausto em que Thomas Mann burila com esmero o seu reincidente tema da doença.

Mas a veemência e a rapidez com que a obra, no decorrer de poucos meses, foi lançada num jato sobre o papel, firmava em mim a ideia de que aquela miséria fisiológica não passara de uma espécie de refúgio e esconderijo, aonde se retirara a natureza de meu amigo, a fim de fomentar seus planos despercebidamente, ao abrigo de quaisquer conjeturas, numa solidão dolorosamente apartada da vida dos sadios, e de desenvolver assim projetos aos quais a saúde normal jamais confere a necessária audácia e que, por assim dizer, precisam ser roubados dos Ínferos, para dali serem carregados à luz do dia. (MANN, 1984, p.480)

"Aquela miséria fisiológica não passara de uma espécie de refúgio e esconderijo". Temos aqui uma metáfora que é fruto da busca do narrador por uma expressão sintética da visão de mundo que autoriza Adrian Leverkühn, o gênio musical atormentado que protagoniza o romance, a fazer sua revolução dodecafônica. Ao longo da narrativa, somos apresentados a um Leverkühn assolado por uma saúde fragilíssima, vítima de crises brutais de enxaqueca que o forçam a se retirar do convívio social. Contudo, é essa mesma falta de saúde que molda a sua autoimagem e lhe confere o ímpeto necessário para emancipar-se das convenções em geral (o que inclui emancipar-se das convenções musicais). Adrian precisa enxergar as coisas dispostas da maneira indicada pela metáfora para produzir obras que demandam de seu autor uma audácia que está para além das possibilidades da "saúde normal".

Julgo que a operação assertórica peculiar contemplada por Glucksberg e Keysar em seu modelo ocorre de modo um tanto proeminente nesse exemplo. É claro que, como metáfora de escritor, a metáfora de Mann apresenta uma série de requintes dignos de nota. A categoria ad hoc que Mann procura estabelecer é elaborada a partir de dois veículos, com a conjunção traçada entre refúgio (Refugium) e esconderijo (Versteck). A categoria refúgio-esconderijo tem sua extensão ampliada de modo a comportar o referente de "miséria fisiológica" - ou condição miserável (Elendszustand) - como um membro seu. "Refúgio" e "esconderijo" passam agora a nomear um rol 
de membros que compartilham menos propriedades salientes e distintivas em comum com os protótipos do que o faziam que aqueles que se tomava como membros-limite nas categorias canônicas - por exemplo, ser um espaço físico é uma propriedade não compartilhada entre a doença de Leverkühn e o protótipo de refúgio. A metáfora de Mann requer do receptor uma seleção das propriedades relevantes das categorias canônicas expressas pelos termos "refúgio" e "esconderijo", de modo a comportar os membros ad hoc designados pelos termos "miséria fisiológica". Essa operação exige, por exemplo, a ocultação das propriedades prototípicas dos espaços físicos que servem de refúgio; em contrapartida, põem-se em relevo as propriedades prototípicas do estar ao abrigo de ameaças. Propriedades prototípicas de esconderijos, como o ser ignorado pelos outros, somam-se ao veículo refúgio e auxiliam na categorização da miséria fisiológica. A doença de Leverkühn era ignorada por quase todos, confundindo-se com sua excentricidade. Deve-se levar em conta que, como vimos, a passagem de nível básico a um nível supraordenado envolve a perda de conteúdo informacional, i.e., passa-e a operar com um número menor de propriedades distintivas. ${ }^{6}$

É ainda de suma importância atentarmos ao seguinte fato: a metáfora de Mann, além de romper com a forma simples " $a$ é $b$ ", trabalhando com um veículo duplo, traz explícita em seu corpo a expressão "uma espécie de". Procedendo de tal modo, o escritor nos permite a seguinte indagação: se a metáfora, como sustentam Glucksberg e Keysar, é efetivamente um tipo de asserção, deve ela admitir receber uma paráfrase estendida na forma " $a$ é uma espécie de $b$ " (ou, nesse caso, " $a$ é uma espécie de $b$ e $c$ "), como admitem as asserções literais? A próxima seção traz algumas distinções entre metáforas categóricas e símiles que talvez nos permitam lançar luz sobre esse ponto.

\section{TRUnfo CONTRA O COMPARACIONISMO}

A ideia de que metáforas promovem categorizações funcionais ad hoc firma o solo para um estudo da ocorrência de nomes próprios como veículos, e esse me parece ser um dos grandes trunfos do MIC. Metáforas como "N.N. é um Shakespeare" desafiam modelos concorrentes (como o Comparacionismo e a Teoria da Metáfora Conceitual) ${ }^{7}$ e caem como uma

6 É digno de nota que outros escritores de expressão tenham chegado a soluções muito semelhantes para o preenchimento das lacunas semânticas que encontraram pela frente, compondo metáforas em que o termo "refúgio" aparece no veículo, p.ex.: "E acaso não era também meu pensamento um refúgio em cujo fundo me sentia oculto, até mesmo para olhar o que se passava fora?" (PROUST, 1946, p.117) e "Senti que na ternura de Paulina havia um refúgio inviolável, onde estávamos a sós” (BIOY CASARES, 2014, p.12)

7 Não é o meu foco no presente trabalho, mas metáforas desse tipo também podem 
luva no modelo desenvolvido por Glucksberg e Keysar.

Focar-me-ei, nesta seção, nos embaraços que esse tipo de metáfora traz para o Comparacionismo e começo, como se faz premente, por explicar mais detalhadamente o que entendo por "Comparacionismo". Trata-se, como já foi dito acima, da teoria da metáfora mais tradicional, remontando a retores latinos como Quintiliano, a qual assume que a compreensão da metáfora envolve uma paráfrase na forma de símile (comparação). Tal assunção destitui a metáfora de qualquer função cognitiva distinta daquela que se obtém mediante símiles - o símile simples, na forma "a é como b", estabelece uma comparação ou correspondência de propriedades (feature matching) e não uma categorização. Podendo o emissor de uma metáfora sempre optar por um modo literal de expressão para dizer o que quer dizer, nada mais restaria à metáfora do que assumir seu papel no interior das tropologias, reduzida a mero capricho estilístico, recurso ornamental. ${ }^{8}$

Vimos também que, em seus primeiros trabalhos juntos sobre o tema da metáfora, Glucksberg e Keysar defenderam uma posição diametralmente oposta ao que defende o comparacionista: sua tese é de que símiles são categorizações metafóricas implícitas (GLUCKSBERG; KEYSAR, 1993, p.415). Contudo, Glucksberg, em trabalhos mais recentes, tem procurado retificar sua teoria no que diz respeito a esse seu antigo posicionamento. Muitos experimentos feitos com o auxílio de sua equipe vêm evidenciando que a operação de correspondência de propriedades (feature matching), própria dos símiles, e a operação de asserção (que ele entende ser própria das metáforas) são muito distintas ${ }^{9}$. Alguns resultados são dignos de nota, como a evidenciação de que certas metáforas sugerem propriedades emergentes

se apresentar como um desafio e tanto para uma das concepções mais influentes dentre as teorias da metáfora em nossos dias. Refiro-me à Teoria da Metáfora Conceitual, desenvolvida por George Lakoff e Mark Johnson em Metaphors We Live By e aprimorada pelos próprios autores e muitos colaboradores desde então. Uma das teses centrais da obra é a de que metáforas correntes são ramificações (entailments) de estruturas conceituais mais gerais, metáforas conceituas, às quais devem sua sistematicidade e coerência. Nesse sentido, "Ele é um Peeperkorn" deveria ser uma ramificação de alguma metáfora conceitual, assim como "Ele atacou meu argumento" é uma ramificação da metáfora conceitual DISCUSSÃO É GUERRA. Mas qual poderia ser a metáfora conceitual por detrás de uma metáfora composta por nomes de indivíduos tanto no domínio-alvo quanto no domínio-fonte? $\mathrm{Na}$ melhor das hipóteses, o que temos é uma fórmula como PESSOA É OUTRA PESSOA ou PESSOA É GRUPO DE PESSOAS. Mas nenhuma das duas construções dá conta da dupla referência assumida pelo termo "Peeperkorn" na metáfora examinada.

8 George Miller e Andrew Ortony são defensores contemporâneos dessa posição. A concepção pragmatista de metáfora (liderada por autores como John Searle e Paul Grice) não resgata inteiramente o comparacionismo, contudo, não rompe com a ideia de que "o sentido literal tem prioridade incondicional no uso da linguagem" (GLUCKSBERG; KEYSAR 1993, p.401) Desse modo, suas posições também são fragilizadas por aquilo que vamos discuti aqui.

9 "Recent evidence on how people understand metaphors and their corresponding similes suggest that both comparison and categorization theories are wrong in this respect. Metaphors and similes differ systematically, and so neither can be interpreted in terms of the other" (GLUCKSBERG, 2008, p.75) 
que os seus símiles correlatos não sugerem. Uma propriedade emergente é aquela gerada pela interação proposicional entre dois ou mais conceitos, sendo que nenhum deles apresenta por si tal propriedade.

Para a metáfora algumas ideias são diamantes*, uma propriedade literal, de nível básico, seria muito valiosas. Em contraste, criativas não é uma propriedade do diamante literal (a pedra preciosa), mas pode se aplicar ao diamante metafórico e, é claro, ao tópico algumas ideias. No [experimento de] parafraseamento de metáforas, foram listadas muito mais propriedades emergentes do que propriedades literais, e a relação reversa também se mostrou verdadeira - foram listadas muito mais propriedades literais do que propriedades metafóricas emergentes, p.ex., raras e desejáveis, tão interessantes que elas brilham e cintilam, muito valiosas. (GLUCKSBERG, 2011, p. 7)

Entretanto, penso que, com base na ocorrência de nomes próprios em metáforas (mais especificamente metáforas em cujo veículo ocorre um nome próprio), podemos chegar a certos apontamentos lógico-gramaticais que se somam aos dados empíricos obtidos por meio de experimentos. Precisamos agora de bons exemplos de metáforas desse tipo e, para tanto, nem precisamos nos dar ao trabalho de importunar outro autor. Demoremo-nos um pouco mais no universo de Mann, tendo em vista que A Montanha Mágica é obra dadivosa a esse respeito.

Não é por acaso - convém reconhecer esse fato - que nos rodeamos de inteligências como as dos Srs. Naphta e Settembrini, ao invés de nos cercarmos exclusivamente de esfumados Peeperkorns. (MANN, 1984, p. 640)

Faço mais uma breve digressão com a finalidade de contextualizar minimamente a metáfora em questão. Os intelectuais Ludovico Settembrini e Leo Naphta, um humanista e o outro jesuíta, disputam, ao longo do romance, o posto de mentor oficial do protagonista Hans Castorp. Mas sua notável erudição sucumbe inerme quando o hedonista Mynher Peeperkorn faz sua entrada majestosa no Berghof - o sanatório que é o cenário de toda a trama. Peeperkorn surge como amante de Clawdia Chauchat, moça russa que volta ao Berghof depois de uma temporada ausente, tendo deixado para trás um enamorado Castorp. O retorno de Clawdia com um amante poderia fazer do mesmo simplesmente o rival do protagonista; todavia, o que temos é Mann torneando, página a página, esse homem recém-chegado. Põe-lhe na face e na boca expressões altivas, faz de sua presença uma presença a um só tempo sedutora e tirânica, em suma, descreve em minúcias as facetas de um homem extraordinário. E faz também com que Castorp não fique alheio a todos es- 
ses atributos de seu concorrente. Em conversa com Settembrini, Castorp se empenha em delinear de uma classe de indivíduos que se destacam não por sua argúcia, não por meras qualidades físicas, mas por um poder de tornar indistinguíveis o "elemento espiritual" e o "elemento corporal", atuando na ordem do "místico". Nas palavras de Castorp, "Para explicar esse fato, dispomos de uma única palavra: personalidade" (MANN, 1984, p. 651). Nesse momento, flagramos o protagonista a eleger um indivíduo que responde pela classe das personalidades, que é o porta-voz dessa classe. Mas mesmo essa palavra, "personalidade" (Persönlichkeit), parece-lhe inadequada para dar conta do que procura dizer, pois, nota que nós a empregamos "também num sentido mais racional, para dizer que se tem personalidade jurídica ou moral ou não sei que personalidades mais" (MANN, 1984, p. 651). Daí Castorp, na passagem citada, precisar recorrer ao emprego do próprio nome do indivíduo prototípico para se referir a uma classe que carece de nome adequado.

Isso posto, voltemos ao exame da metáfora averiguando se não temos em mãos outro belo exemplar de inclusão em classe via metáfora. A metáfora de Mann toma lugar no seio de um contraste, traçado por Castorp, ao posicionar os dois mentores, de um lado, e o holandês majestoso, de outro. O protagonista estabelece esse contraste de um modo um tanto curioso, imaginando a constrangedora existência que levaria caso estivesse rodeado de indivíduos dotados com as características proeminentes de Peeperkorn. Em sua elaboração do contraste entre os intelectuais e indivíduos dotados de tais características, Castorp lança mão do plural do nome do indivíduo prototípico, ele fala em "Peeperkorns". Já procurei mostrar, em trabalhos recentes, que essa possibilidade do plural do nome próprio nessa posição, bem como o uso do artigo indefinido antecedendo o mesmo, são marcas textuais de que o nome não está operando com sua referência usual, i.e., não está designando um indivíduo singular (GURGEL, 2015). O termo no plural "Peeperkorns", com o qual nos deparamos na metáfora acima, é um modo de designação de uma classe que tem como alternativa à expressão "um Peeperkorn". Quero dizer: em contexto correntes, as proposições "Ele é um Peeperkorn", "Ele é um tipo (espécie) de Peeperkorn" e "Ele é um membro da classe dos Peeperkorns" são perfeitamente intercambiáveis - se uma é verdadeira, todas são verdadeiras, se uma é falsa, todas são falsas. Em todas elas ocorre a inclusão do mesmo indivíduo ("ele") em uma mesma categoria ad hoc de ordem superior nomeada a partir do membro típico Peeperkorn.

E aqui se apresenta a oportunidade de tecermos um apontamento valiosa no que tange os ataques ao Comparacionismo que se pode fazer a partir do MIC: a metáfora "Ele é um Peeperkorn", na condição de asserção, resiste à conversão a símile e nisso se distingue de metáforas em que o nome próprio ocorrente na função de veículo não se refere a uma classe. $A$ 
Montanha Mágica também pode nos fornecer um exemplo de metáfora desse último tipo. Durante os festejos de carnaval do Berghof, Settembrini observa a entrada de Clawdia Chauchat, com a devida fantasia, no salão e endereça um comentário ao apaixonado Castorp: "Repara! (...) É a Lilith" (MANN, 1984, p. 366). "Clawdia é Lilith" é uma metáfora cuja conversão em símile não implica uma perda de conteúdo semântico ou alteração das condições de verdade. Vejamos o porquê.

Concordo com Glucksberg $(2011$, p. 3) quando ele afirma que comparação e categorização são duas formas distintas de compreensão. Contudo, ainda que o autor tenha trabalhado em uma revisão na sua antiga tese de que símiles são inclusões em classe implícitas (reduzindo a operação da comparação à operação da categorização), ele não chega a admitir que símiles e metáforas assertivas são tipos diferentes de metáfora. Penso que basta não negligenciarmos o tão antigo quanto contundente estudo da analogia feito por Aristóteles para obtermos uma maneira bem clara de traçar essa distinção. Analogias ou metáforas proporcionais (na forma " $a$ $: b:: c: d$ ", ou seja, " $a$ está para $b$ como $c$ está para $d ")$ rendem bons símiles, quero dizer: não há ruídos em sua conversão em paráfrases na forma de símile. Isso se dá justamente porque uma analogia nada mais é que o estabelecimento ocasional de uma proporção, fundando-se em uma relação de identidade que se restringe a propriedades selecionadas. A identidade que se estabelece entre a relação $a: b$ e a relação $c: d$ é que garante uma semelhança metafórica entre $a$ e $c$. Essa estrutura fica mais explícita em analogias em que, ao invés de dois, três ou mesmo os quatro termos da proporção são explicitados. Por exemplo: "Clawdia é a Lilith de Castorp" dá a entender que, no esquema analógico proposto, Clawdia está para Castorp assim como Lilith (demônio dos ventos e primeira mulher, segundo $O$ Alfabeto de Ben-Sira e escritos apócrifos) está para Adão. Ainda que não estabeleça uma identidade perfeita (literal), como em "A estrela da manhã é Vênus", a analogia estabelece uma identidade de relação e, para tanto, sua cópula deve operar com um sentido identitivo. Esse sentido identitivo da cópula em analogias se distingue claramente do sentido assertórico da cópula em metáforas que efetuam inclusões em classe, como "Ele é um Peeperkorn".

Assim, a metáfora proporcional (analógica) admite a paráfrase na forma de símile e funda-se em uma relação de identidade restrita a propriedades selecionadas, mas, em seu "como", admite que tais propriedades não são suficientes para uma inclusão em classe. Mas há um outro tipo de metáfora, a metáfora categórica, a qual só admite paráfrases que ressaltem sua natureza assertórica - esse é o caso da metáfora que extraimos do Doutor Fausto ("Miséria fisiológica é uma espécie de refúgio"). Dizer que "a é um tipo de $b$ " ou "espécie de $b$ " é tão somente explicitar a força assertórica da 
proporisção " $a$ é um $b$ ". Em sentenças literais, não é diferente: posso dizer que "A rosa é uma flor" ou que "A rosa é uma espécie de flor".

Testemos ainda uma outra via de argumentação: assim como ocorre com asserções literais, as asserções metafóricas podem ser expressas em uma forma que explicite sua operação de instanciação ou subsunção. Posso dizer "A rosa é uma flor", "a rosa é um tipo de flor" ou "a rosa é um membro da classe das flores" e, do mesmo modo, "Ele é um Peeperkorn", "Ele é um tipo de Peeperkorn" ou "Ele é um membro da classe dos Peeperkorns". O Comparacionista afirma que toda metáfora é símile abreviado, ou seja, resolve-se em um símile (bastando, para tanto, o acréscimo da partícula comparativa "como"). Se assim fosse, a metáfora "Ele é um membro da classe dos Peeperkorns" deveria encontrar sinonímia no símile "Ele é como um membro da classe dos Peeperkorns". Porém, isso não ocorre. O símile em questão não é paráfrase da metáfora supostamente correlata. O tópico do símile, "ele", passa a ser comparado com um membro da classe dos Peeperkorns, nada sendo dito sobre o mesmo pertencer efetivamente a tal classe. Temos algo como: ele é como se fosse, sob tal aspecto, um membro da classe dos Peeperkorns. Não se pode, nesse caso, afastar a hipótese de que ele seja portador de alguma outra propriedade distintiva, não expressa na oração, que o impedisse de ser incluído na categoria. Desse modo, não se pode nem mesmo afastar a hipótese de uma distinção entre os valores de verdade do símile e da metáfora: podemos conceber uma situação tal em que se possa dizer de um mesmo indivíduo que ele se parece com um membro da classe dos Peeperkorns sem, com isso dizer, que ele pertença à classe. Ele se parece por se vestir de modo semelhante, por exemplo. Nesse caso, o símile ("Ele é como um membro da classe dos Peeperkorns") seria verdadeiro e a metáfora ("Ele é um membro da classe dos Peeperkorns"), falsa.

Dizer que a conversão de certas metáforas em símiles mitiga a asserção é dizer que se altera o compromisso que assume o emissor com a ideia de que as propriedades destacadas na sentença devem ser tomadas como distintivas. Usando o "como", o emissor admite a fragilidade, a aplicabilidade muito restrita e ocasional de seu juízo. Ele não se compromete com uma recategorização, não afirma que " $a$ é um tipo de $b$ ". Em suma, o símile não assume um compromisso ontológico forte, como bem nota Julio Cortázar, em seu Bestiário: "como isto, como aquilo; mas nunca como é de verdade.” (CORTÁZAR, 1971, p. 74)

Uma derradeira consideração se faz premente ainda nessa seção: temos, em "Ele é um Peeperkorn", uma metáfora cujo protótipo não é parte da bagagem cultural do leitor. Mann constrói o indivíduo realçando suas propriedades prototípicas, para, mais à frente, empregar o nome desse indivíduo como nome de uma classe de indivíduos. Nesse caso, não temos uma 
categoria de base à maneira de Rosch. (Esse é um dos inúmeros casos em que a inventividade literária vai exigir de uma teoria da metáfora mais do que a Teoria dos Prototipos em sua versão original).

\section{DAS EXCEÇÕES: NEGAÇÕES METAFÓRICAS E CATEGORIAS SUBORDINADAS AD HOC ESTABELECIDAS POR METÁFORA}

Vimos que o MIC é capaz de acomodar metáforas literárias muito engenhosas. Todavia, é sempre recomendável não perdermos de vista o grave adágio de Wittgenstein: "Nada é tão difícil quanto fazer justiça aos fatos" (WITTGENSTEIN, 1993, p.128). Se a tarefa dos estudiosos da linguagem natural que ousam trabalhar com exemplos literários é delinear padrões de ocorrência, a tarefa dos literatos parece ser a de arruinar qualquer pretensão teórica nesse sentido. Basta que se estabeleça uma fórmula geral da metáfora para que pululem fatores complicadores e exceções à regra. No caso do MIC, eis os problemas mais imediatos:

\section{1) Como aplicar o MIC a metáforas em que ocorre uma negação?}

Por que essa fixação em metáforas que, tomadas literalmente, se apresentam como falsidades patentes? Metáforas podem ocorrer na forma de negação, constituindo, em geral, truísmos. Tomemos como exemplo de metáfora negativa a célebre frase de John Donne, "Nenhum homem é uma ilha". Analisando essa proposição universal negativa à maneira aristotélica, temos: "Todo homem não é uma ilha". Essa formulação da metáfora deixa ainda mais patente que não temos diante de nós um caso de inclusão em classe. Se a metáfora afimativa simples promove uma ampliação da extensão da categoria nomeada no veículo, de modo a abarcar o tópico, a metáfora negativa limita-se a apresentar um tópico que não pode ser subsumido à categoria nomeada no veículo. Ocorre, é verdade, a formação e a nomeação da classe de ordem superior ("ilha", que nomeia a ilha canônica, serve de base para o estabelecimento da categoria nomeada como "ilha"); porém, não ocorre uma instanciação. Talvez a constatação de que ocorre efetivamente a formação e a nomeação da classe superior seja o bastante para afirmarmos que o modelo desenvolvido por Glucksberg e Keysar acomoda negações nominais metafóricas. Mas, de qualquer modo, fica explícito que a operação de inclusão em classe não goza de exclusividade no reino das metáforas nominais.

Um outro exemplo: o próprio desenvolvimento da trama de $A$ Montanha Mágica nos permite estabelecer um curioso exemplo de negação 
metafórica. O quadro da doença do Sr. Peeperkorn se agrava a olhos vistos e o mesmo já não consegue sustentar por muito tempo sua postura intensa e dominadora. O homem que serve de modelo para a formação da categoria metafórica vai, aos poucos, deixando de ser um membro dessa mesma categoria. Ao fim e ao cabo, encontramos o Sr. Peeperkorn frágil e acamado, dando apenas vislumbres da Personalidade que fora outrora. Se, pedindo licença a Mann, imaginarmos Castorp resgatando sua metáfora diante da cama do moribundo - quero dizer, resgatando a categoria dos Peeperkorns anteriormente estabelecida - teremos um contexto propício para a postulação do seguinte juízo metafórico: "Peeperkorn não é um Peeperkorn". Nesse caso, além de não se configurar uma inclusão em classe, temos também uma curiosa exclusão daquele que antes fora tomado como o membro prototípico da classe.

2) Como aplicar o MIC a metáforas nominais nas quais nem tudo o que cai sob a categoria canonicamente designada pelo nome do predicado (veículo) cai sob a categoria metaforicamente designada por esse mesmo nome?

Vimos que metáforas nominais categóricas e afirmativas operam inclusões em classe, de forma que todos os membros da categoria, a que $o$ nome predicado faz canonicamente referência, são membros da categoria ad hoc a que o nome do predicado faz metaforicamente referência. Dessa forma, toda categoria estabelecida e nomeada por metáfora seria supraordenada. Entretanto, parece-me bem razoável perguntar se, assim como há metáforas atuando no estabelecimento e nomeação de categorias supraordenadas, não poderia haver metáforas atuando no estabelecimento e nomeação de categorias subordinadas. Ou seja: se elas podem atuar ampliando categorias, não poderiam também fazer a operação oposta?

Essa pergunta nos remete a um abalo na MIC. Se o modelo desenvolvido por Glucksberg e Keysar se mostra promissor para o exame de metáforas de invenção ao se fundar na ideia de que metáforas podem ser recursos de nomeação de categorias anônimas, mostra-se também limitado para esses mesmos fins ao se comprometer com a Teoria do Protótipo em sua versão padrão. A versão padrão desenvolvida por Rosch, como vimos, assume que um protótipo, exemplar mais típico, governa a estruturação de uma categoria e que as bordas extensionais da mesma são difusas ${ }^{10}$. Mas não são raros os casos, nos sistemas de linguagem correntes, de categorias que ou não apresentam um protótipo, ou apresentam mais de um protótipo

10 Estou desconsiderando aqui a autocrítica ainda incipiente feita em trabalho de 1979. 
ou, ainda, mostram-se casos de categorias cujas bordas não são difusas. A própria categoria dos protótipos é uma categoria não estruturada com base em um protótipo (assim como as categorias de regra, ou crença). Cachorro é uma categoria que pode envolver, em muitos socioletos, mais de um protótipo (um para os cachorros de madame e outro para os vira-latas, $\mathrm{p}$. ex.). A categoria dos números ímpares, a seu turno, não apresenta nem um protótipo único, nem bordas difusas (experimentos mostram que " 3 ", " 5 ", "7" e "9" são seus protótipos e que a propriedade "número não divisível por 2 " torna seu campo extensional muito bem delimitado) ${ }^{11}$.

Georges Kleiber propôs mais recentemente uma versão estendida da Teoria dos Protótipos (versão que é, na verdade, uma reformulação bem radical daquela teoria). Para superar as diversas falhas da teoria padrão, Kleiber sustenta que os protótipos ainda podem ser tomados como exemplares idôneos de categorias, mas nos adverte quanto ao fato de que categorias naturalmente formadas não teriam protótipos como seus elementos fundadores ou ordenadores: o protótipo "como já não tem uma origem única e pode aparecer inclusive nas categorias clássicas (número ímpar) já não possui o estatuto de entidade fundadora (...)" (KLEIBER, 1995, p. 144).

De acordo com Kleiber, a relação de vinculação entre os membros de uma categoria obedeceria, via de regra, à semelhança de família proposta por Wittgenstein $(2006, \S 67)$ (não sendo mandatório que certas propriedades do chamado membro típico sejam pervasivas). Kleiber trabalha com uma concepção abstrata de protótipo: trata-se de um esquema que reúne as propriedades típicas de uma categoria e pode receber o nome de um exemplar da mesma. E, assim, o protótipo passa a ser visto como efeito da estrutura categorial. O protótipo assume formas diferentes, dependendo do modelo da categoria da qual é efeito, de modo que se torna mais adequado falar em "efeito prototípico".

Uma consequência da revisão proposta por Kleiber nos interessa diretamente aqui: sua versão estendida oferece espaço para se trabalhar com categorias que aceitam mais de um protótipo e com a presença de propriedades prototípicas antagônicas no interior de uma mesma categoria. Desse modo, é o contexto e, eventualmente, as características explicitamente atribuídas ao tópico que vão nos orientar na determinação de quais propriedades convém ao veículo.

Diante deste quadro, podemos nos perguntar: o que nos impede

11 "testes psicológicos estabelecem que os números ímpares, do um ao nove, constituem idôneos representantes do conceito de número ímpar. Esta prototipicidade, contudo, não implica o limite difuso; o conceito possui uma definição muito precisa (número não divisível por dois) o qual proporciona uma aplicabilidade referencial desprovida de toda flutuação" (KLEIBER, 1995, p. 136). 
de conceber metáforas em que alguma(s) propriedade(s) do tópico anule(m) justamente aquela(s) propriedade(s) do veículo que sustentaria(m) a permanência de um ou mais membros da categoria canônica no interior da categoria ad hoc? Vejo ao menos três modos de algo assim ocorrer em metáforas nominais:

2.1. Quando uma determinada categoria apresenta subclasses (categorias subordinadas) bem delineadas e com propriedades antagônicas, de modo que o veículo da metáfora atua conferindo o nome da categoria como um todo somente a uma das categorias subordinadas. Em "Esse carro é animal", proferida em um contexto em que um carro esporte é elogiado, as propriedades prototípicas ressaltadas no veículo não dizem respeito a um membro prototípico único ou à categoria canônica (e taxionômica) dos animais como um todo. Elas dizem respeito somente a certos exemplares da subclasse dos predadores, com sua ferocidade e voracidade, seu rosnar amedrontador. Desse modo, uma ovelha, animal conhecido por sua docilidade e balidos passivos, por mais que seja um animal em um sentido canônico, não é um animal em um sentido metafórico.

Uma derivação lógica um tanto curiosa, a qual se repetirá nos casos subsequentes: insinua-se, em casos de nomeação de categorias ad hoc subordinadas via metáfora, a regra "Nem todo $b$ canônico é $b$ metafórico" (sendo $b$ o nome do veículo). Essa é uma diferença marcante entre esse tipo de categoria formada por metáfora e as demais - Tal regra não se aplica a uma metáfora de categorização supraordenada como "Meu trabalho é uma prisão" ou a uma metáfora proporcional como "Ela é a Gisele Bündschen da festa". A bem da verdade, essa regra só reflete o fato de que categorias ad hoc subordinadas (ou de sofisticação) estabelecidas via metáfora apresentam ao menos uma propriedade saliente que não constava dentre as propriedades prototípicas da categoria canônica da qual se derivam.

2.2. Quando certas propriedades prototípicas taxionômicas divergem de certas propriedades prototípicas estabelecidas pelo senso-comum (propriedades estereotípicas). Esse é o caso de uma metáfora como "Esse policial é um gorila" em um contexto de ofensa. Chamar um policial de "gorila" é evocar, como bem diz Max Black, um sistema de lugares-comuns associados a esse termo, crenças standard acerca dos gorilas (BLACK, 1955, p.287). Animais grosseiros e violentos. Tais lugares-comuns (o estereótipo), contudo, não estão de acordo com o que a zoologia estabelece acerca desses animais - sua postura pacífica e esquiva. Desse modo, boa parte dos membros da categoria canônica (taxionômica) dos gorilas não se deixa subsumir à categoria metafórica dos gorilas - nem todo gorila é um gorila. Poder-se-ia aqui sair 
em defesa do MIC, afirmando que, nesse caso, temos categorias de origem diferentes compartilhando um mesmo nome - um caso de polissemia, ou para ser mais preciso, de homonímia. A alegação seria de que na proposição metafórica "Esse policial é um gorila" e a proposição literal "Esse primata é um gorila" o termo "gorila" teria referentes distintos. Entretanto, trata-se de uma evasiva, uma vez que a classe zoológica dos gorilas e a classe estereotípica dos gorilas não somente estão ligadas por uma clara relação (impertinente) de derivação como disputam o mesmo referente. E é claro que se pode fazer metáforas com esse mesmo veículo ("gorila"), nos contextos apropriados, ressaltando-se, ao invés das propriedades estereotípicas, as propriedades reais ou taxionômicas.

\subsection{Quando uma determinada categoria abarca propriedades prototípicas} antagônicas, porém não há delineação canônica de subclasses (categorias subordinadas), de modo que o veículo da metáfora atua conferindo o nome da categoria como um todo somente a uma coleção de propriedades congruentes entre si e exclui quaisquer outras propriedades (e, a reboque, membros dotados com tais propriedades) que sejam incongruentes com aquelas. Nesse caso, a explicitação de certa(s) propriedade(s) do tópico ou da relação entre tópico e veículo (por meio da introdução de adjetivos ou advérbios, p.ex.) é bem vinda na orientação do receptor no que diz respeito a quais propriedades prototípicas do veículo devem ser ressaltadas e quais devem ser ocultadas.

Clarice Lispector, em Água Viva, oferta-nos um exemplo de como esse tipo de metáfora pode se mostrar um sofisticado recurso literário.

É com uma alegria tão profunda. É uma tal aleluia. Aleluia, grito eu, aleluia que se funde com o mais escuro uivo humano da dor de separação mas é grito de felicidade diabólica. Porque ninguém me prende mais. (LISPECTOR, 1973, p. 9)

A característica distintiva da metáfora construída nessa passagem é a atribuição de uma propriedade saliente ao referente do tópico (sujeito), a qual, em detrimento de ser incompatível com certas propriedades salientes de membros prototípicos, deve ser mantida na instanciação. No caso, a propriedade do "ser diabólico", atribuída ao grito de felicidade, à alegria profunda com que a personagem inicia o texto, entra em antagonismo com a relação prototipicamente estabelecida entre a expressão "aleluia" e a esfera do divino. "Aleluia" é sabidamente um termo carregado por uma forte associação com contextos religiosos (de louvor ao divino), sendo um uso canônico do termo aquele que se refere a uma manifestação verbal com propriedades prototípicas como as seguintes: é forma de celebração, feita em louvor a Deus, geralmente em templo religioso, e em tom exclamativo. 
Na passagem, contudo, fala-se em "uma tal" aleluia (um tipo de aleluia) que admite, ao modo de um oxímoro, a adjetivação "diabólica". Essa propriedade ressaltada e atribuída ao tópico da metáfora, o grito, assume um papel central, portanto. Ela nos leva a excluir, na passagem da categoria canônica à categoria ad hoc, um ou mais membros típicos da primeira e todos aqueles que com ele(s) compartilham a propriedade incongruente.

Decerto, há propriedades salientes compartilhadas entre o grito da personagem e a manifestação religiosa (como ser forma de celebração e ocorrer em tom exclamativo), e elas podem perfeitamente atuar como parâmetros para a compreensão da metáfora. O emprego do termo "diabólica" perece mesmo visar esse estabelecimento e nomeação da categoria ad hoc por contraste. Mas seria não fazer jus à metáfora de Lispector se a reduzíssemos somente ao contraste, somente ao pão-com-queijo-sem-queijo. Certo processo diacrônico de uso conferiu ao termo "aleluia" um segundo uso muito frequente, a saber, aquele em que "aleluia" é uma manifestação verbal de alívio, sinônimo de "finalmente!". Parece-me um tanto evidente que Lispector está jogando com isso ao inserir no texto alguns dispositivos que nos orientam a admitir essa aleluia de alívio na categoria ad hoc ao mesmo tempo em que interditamos a aleluia de louvor religioso. Um desses dispositivos é a ênfase no sentimento de alegria profunda diante de uma separação (não obstante os inevitáveis traços de dor) com que se faz a manifestação exclamativa. A ênfase no tema da separação fornece as bases para a inclusão de pelo menos um membro prototípico da categoria canônica de aleluia nessa categoria ad hoc engendrada por Lispector. O desatrelamento entre a aleluia de alívio e a aleluia religiosa em nossa língua chega a tal ponto que se faz possível estabelecer categorias ad hoc em que somente um dos dois figura.

Desse modo, na dupla referência assumida pelo termo "aleluia" por ocasião da metáfora, a referência primária ou canônica já não é de nível básico (todos os membros da categoria aleluia) e sim de nível subordinado (os membros da categoria aleluia sem traços religiosos), de maneira que a referência ad hoc é fruto de uma ampliação da extensão não da categoria aleluia como um todo, mas somente desse nível subordinado (coleção exclusiva de propriedades prototípicas, muitas das quais presentes na aleluia de alívio) que não chega a ser uma categoria subordinada. É justamente por conta desse recorte, dessa exclusividade, que se faz aplicável a constatação de que nem toda aleluia é uma aleluia, tomando-se o primeiro termo em um sentido canônico e o segundo em um sentido metafórico. É muito relevante destacar o fato de que, nessa operação metafórica, o tópico ("grito de 
felicidade diabólica") ${ }^{12}$ não é passivamente incluído na categoria ad hoc. Uma de suas propriedades (o ser diabólico) se impõe, tomando o lugar de propriedades salientes do veículo e, assim, desempenhando papel ativo no estabelecimento dessa mesma categoria.

Vimos anteriormente que, de acordo com a Teoria dos Protótipos, uma categoria de ordem superior é mais econômica, porém, menos informativa do que uma de ordem inferior. Assumindo que as categorias formadas por metáfora são sempre de ordem superior Glucksberg e Keysar assumem também que elas são sempre mais vagas, apresentando menos propriedades prototípicas. O que esses exemplos mostram é que isso não é sempre assim. Podemos encontrar categorias formadas por metáforas que têm tanto ou mais conteúdo informacional que as categorias de que são derivadas e, logo, que elas podem ter mais especificidade e sofisticação do que as mesmas.

\section{ConCLUSÃo}

Procurei mostrar que o Modelo da Inclusão em Classe (MIC), fundado, de um lado, na Teoria dos Protótipos e, de outro, na tese da existência de categorias funcionais ad hoc, mostra-se muito mais aplicável ao estudo de metáforas novas ou de invenção do que o modelo tradicional que aqui denominamos "Comparacionismo". A ideia central desse modelo desenvolvido por Glucksberg e Keysar, a saber, a de que metáforas são efetivamente proposições em um sentido estrito - mas com a peculiaridade de estabelecer categorias ad hoc a partir da alteração da extensão de categorias comuns -, permite-nos compreender que seu campo de atuação não é necessariamente o ornamental e nem mesmo o ficcional. Uma categoria funcional ad hoc como a do refúgio não precisa se restringir a orientar personagens fictícios como Adrian Leverkühn em suas façanhas musicais. Pode-se, perfeitamente, aplicar tal categoria a uma pessoa real, de modo a explicar, por exemplo, o que a leva a agir de tal e tal maneira. "O álcool era seu refúgio". O mesmo para a categoria dos Peeperkorns. "Meu irmão é um perfeito Peeperkorn".

12 Para respeitar a estrutura sintática do texto, o mais correto seria dizer que o tópico imediato da metáfora em questão é "alegria profunda". Mas, na sequência, fica patente que essa alegria peculiar toma forma tanto no "grito de felicidade diabólica" quanto em uma espécie de canto pagão. "E canto aleluia para o ar assim como faz o pássaro. E meu canto é de ninguém. Mas não há paixão sofrida em dor e amor a que não se siga uma aleluia” (LISPECTOR, 1973, p.10). A proeminência do traço diabólico do grito é informação relevante para que o leitor tenha olhos para o laicismo (no sentido do que é alheio a assuntos religiosos) que há nos cantos da mulher e do pássaro, os quais cantam não para Deus, mas "para o ar”. Entendo que a ênfase textual nesse laicismo contribui para o estabelecimento da categoria ad hoc que a autora começara a apresentar na página anterior. 
Um dos grandes méritos do MIC é nos fazer ver que certas metáforas podem assumir um forte compromisso cognitivo, ou seja, que as metáforas categóricas se comprometem com descrições de fatos, apresentando valor de verdade. Uma implicação direta dessa constatação para o estudo da ocorrência de metáforas em narrativas ficcionais é a de que as categorias ad hoc estabelecidas por metáforas não são necessariamente categorias ficcionais. Categorias metaforicamente estabelecidas em textos literários podem apresentar grande veemência ontológica. Advertido quanto ao fato de que "Meu irmão é um perfeito Peeperkorn", o Sr. N.N. passa a tratá-lo de outro modo. Lakoff e Johnson, em Metaphors We Live By, são muito contundentes ao afirmar que nós não só compreendemos os fatos por meio de metáforas como também agimos a partir dessa compreensão. A compreensibilidade e a pertinência de uma metáfora se relacionam diretamente com as ações sancionadas pela mesma ${ }^{13}$.

Como se vê, os méritos do MIC não são poucos. Contudo, em face da sofisticação das metáforas que submetemos a exame, vi-me impelido, nas últimas seções deste trabalho, a propor algumas complementações ao modelo estabelecido por Glucksberg e Keysar. Uma dessas complementações diz respeito ao fato de que, sobretudo em narrativas ficcionais, deparamo-nos não apenas com a composição de metáforas novas, mas com o estabelecimento das propriedades prototípicas que permitirão o estabelecimento daquelas. Trata-se de um retorno à pergunta feita na introdução deste trabalho: em que as metáforas poderiam auxiliar um escritor em sua tarefa de estabelecer e nomear de categorias obscuras, de difícil apreensão? Vimos, por exemplo, como as metáforas podem atuar na construção das personagens. Metáforas como "Ele é um Peeperkorn" nos mostram que, assim, como a personagem, a metáfora com seu nome é preparada ao longo de muitas páginas. Uma metáfora como essa difere claramente de outra como "Ele é um Shakespeare”, uma vez que, nesse último caso, as propriedades prototípicas do veículo já estão estabelecidas no imaginário da comunidade linguística de que faz parte o receptor.

O estudo de metáforas novas estabelecidas a partir de propriedades tornadas prototípicas no próprio ato da leitura (ao longo de muitas páginas) exige uma abordagem teórica não ao nível da sentença, mas ao nível do discurso. Fica para um próximo trabalho a elaboração da seguinte sugestão: um modo promissor de abordar a metáfora do ponto de vista de

13 "Though questions of truth do arise for new metaphors, the more important questions are those of appropriate action. In most cases, what is at issue is not the truth or falsity of a metaphor but the perceptions and inferences that follow from it and the actions that are sanctioned by it" (LAKOFF; JOHNSON, 2003, p. 158). 
sua inserção em um discurso é tomá-la como lance em um jogo de linguagem (WITTGENSTEIN, 2006, §49). A metáfora, em sua forma sentencial, é examinada levando-se em conta as articulações linguísticas que a precedem e que a sucedem. O caso da metáfora de Thomas Mann é um caso de construção de um protótipo ao longo da narrativa, "as we go along" (WITTGENSTEIN, 2006, §83), para depois levar o leitor a tomar o nome desse personagem como o nome de um tipo de indivíduo. Com isso, Mann logra nomear, via metáfora, uma categoria não só concebível, mas familiar.

Quanto aos problemas que o presente trabalho assume ter encontrado no MIC, uma primeira fonte de problemas é a seguinte: Glucksberg e Keysar agem temerariamente ao estabelecer uma fórmula única para tudo o que se pode chamar de "metáfora nominal". Esse passo em falso conduz a muitas dificuldades, duas das quais foram tratadas aqui: negligencia-se tanto as peculiaridades das metáforas analógicas e símiles - que não assumem o mesmo compromisso ontológico que pode assumir uma metáfora categórica -, quanto as peculiaridades das negações metafóricas - que não promovem, como vimos, inclusões em classe. Discordando da tese inicial dos autores de que símiles são categorizações implícitas, procurei mostrar que não só os símiles, mas também as metáforas analógicas apresentam um modo de operar distinto daqueles que encontramos em metáforas categóricas. Enquanto a metáfora analógica se faz satisfatoriamente conversível em símile, a metáfora categórica não pode ser parafraseada desse modo sem perda de conteúdo cognitivo.

Na última seção deste artigo, apresentei uma outra fonte de problemas do modelo: Glucksberg e Keysar atém-se a uma versão padrão da Teoria dos Protótipos e tal teoria não abre espaço para que se pense a presença de propriedades prototípicas divergentes e mesmo antagônicas no interior de uma mesma categoria. Procurei mostrar que metáforas categóricas dividem-se em, pelo menos, dois tipos distintos: as que estabelecem categorias ad hoc de ordem superior e as que estabelecem categorias ad hoc de ordem inferior (mais especializadas, exclusivas), e que o MIC não contempla metáforas categóricas desse último tipo - no qual se enquadram metáforas literárias muito sofisticadas, como a metáfora da aleluia, de Clarice Lispector.

A ideia de que asserções metafóricas nominais envolvem unicamente a ocultação de propriedades impede o MIC de revelar os mecanismos internos de metáforas que estabelecem categorias subordinadas - metáforas em que ao menos uma propriedade do tópico é tornada prototípica de forma a anular uma propriedade prototípica responsável por vincular certos membros à categoria canonicamente nomeada pelo termo do veículo. Eliminada essa ideia precipitada, muitas possibilidades se abrem para o estudo da metáfora categórica. 


\section{REFERÊNCIAS}

BARSALOU, L.W. Ad hoc categories. Memory \& Cognition, v. 11, n. 3, p. 211-227, 1983.

BIOY CASARES. Em memória de Paulina. In: . Obras Completas 1940-1958. Tradução de Sérgio Molina et al. São Paulo: Biblioteca Azul/Globo, 2014.

BLACK, M. Metaphor. Proceedings of the Aristotelian Society, v. 55, p. 273-294, 1955.

CORTAZAR, J. Bestiário. 2 ed. Tradução de Remy Gorga Filho. São Paulo: Expressão e Cultura, 1971.

GLUCKSBERG, S. Understanding Metaphors: the paradox of unlike things. In: AHMAD, K. (ed.). Affective Computing and Sentiment Analysis: Emotion, metaphor and terminology. London: Springer, 2011. p. 1-12.

. How metaphors create categories - quickly. In: GIBBS JR., R. The Cambridge Handbook of Metaphor and Thought. Cambridge: Cambridge University Press, 2008.

GLUCKSBERG, S.; KEYSAR, B. Understanding Metaphorical Comparisons: Beyond Similarity. Psychological Review, v. 97, n. 1, p. 3-18, 1990.

. How metaphors work. In: ORTONY, A. (ed.). Metaphor and Thought. Cambridge: Cambridge University Press, 1993. p. 401-424.

GLUCKSBERG, S.; KEYSAR, B.; SHEN, Y.; HORTON, W. Conventional Language: How metaphorical is it?. Journal of Memory and Language, n. 43, p. 576-593, 2000.

GURGEL, D. Nomes próprios como nomes de classes em textos ficcionais. Eutomia, v. 1, n. 15, p. 199-233, 2015.

KEYSAR, B; GERNSBACHER, M. A; ROBERTSON, R. R.W; WERNER, N. K. The role of suppression and enhancement in understanding metaphors. Journal of Memory and Language, n. 45, p. 433-450, 2001.

KLEIBER, G. La sémantique du prototype. Paris: PUF, 1990.

Hiérarquie Lexicale: catégorisation verticale et termes de base. Sémiotiques, v. 1, n. 1, p. 35-57, 1995.

LAKOFF, G.; JOHNSON, M. Metaphors We Live By. Chicago: The University of Chicago Press, 2003.

LIMA, G.A. Modelos de categorização: apresentando o modelo clássico e o modelo de protótipos. Perspectivas em Ciência da Informação, v. 15, n. 2, p. 108-122, 2010.

LISPECTOR, C. Água Viva. Rio de Janeiro: Editora Artenova, 1973.

MANN, T. Doutor Fausto: a vida do compositor alemão Adrian Leverkühn narrada por um amigo. Tradução de Herbert Caro. 2.ed. Rio de Janeiro: Nova Fronteira, 1984.

Doktor Faustus: das Leben des deutschen Tonsetzers Adrian Leverkühn erzählt von

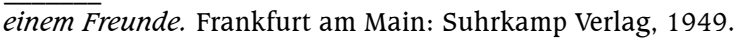

. A Montanha Mágica. Tradução de Herbert Caro. Rio de Janeiro: Nova Fronteira, 1984. . Der Zauberberg. Frankfurt am Main: Fischer Verlag, 1952.

PROUST, M. A la Recherche du Temps Perdu I: Du Côte de chez Swann. Paris: Gallimard, 1946. QUINTILIANO. Institutio Oratoria. Tradução de H. E. Butler. Cambridge: Harvard University Press, 1953.

ROSCH, E. H. Natural Categories. Cognitive Psychology, n. 4, p. 328-350, 1973. 
ROSCH, E. H. et al. Basic Objects in natural Categories. Cognitive Psychology, n. 8, p. 382-439, 1976.

. Principles of Categorization. In: ROSCH E. H.; BARBARA, L. (eds.). Cognition and Categorization. Hillsdale, NJ: Lawrence Erlbaum, 1978. p. 27-48.

WITTGENSTEIN, L. Tractatus Logico-Philosophicus; Tagebücher 1914-1916; Philosophiche Untersuchungen. Frankfurt am Main: Suhrkamp, 2006.

. In: KLAGGE, J. C.; NORDMANN, A. (Eds.).Philosophical Occasions 1912-1951. Indiana: Hackett Publishing Company, 1993.

Submetido em: 09/03/2016

Aceito em: 12/05/2016 